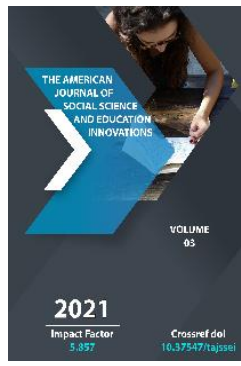

Journal Website: http://usajournalshub.c om/index,php/tajssei

Copyright: Original content from this work may be used under the terms of the creative commons attributes 4.0 licence.

\section{The Role Of Bukhara Jews In The Development Of Natiaonal Makom Art}

\author{
Abdumutal Ahadjonovich Qambarov \\ Associate Professor, Candidate Of Philosophical Sciences, Fergana State University, Uzbekistan \\ Mavluda Mamasodikovna Najmetdinova \\ Lecturer, Fergana State University, Uzbekistan
}

\title{
ABSTRACT
}

This article analyzes from a scientific and philosophical point of view that the Jews of Bukhara, along with the Uzbek makoms, have made a worthy contribution to the development of Shashmakom to this day through the work of masters of their profession, hafiz, musicians and composers.

\section{KEYWORDS}

Shashmakom, makomdon, hafiz, musician, composer, artist, performance, customs, suporish, Avji Turk, Zebo Pari, and Muhayyari.

\section{INTRODUCTION}

Status is the priceless spiritual heritage of our people. This art has gone through a long period of development, many hafiz artists, composers and singers have contributed to its gradual development. They (A.Q. in Shashmakom) embody the most delicate tones of human experiences. Speaking of classical makoms, our minds naturally embody the image of master 
artists who have shown spiritual courage and zeal in the difficult conditions of the recent past in the transmission of this priceless value to us.

Bukhara is the homeland of Shashmakom and the place where this art was developed. Bukhara is also a multi-ethnic city, embodying the brightest examples, traditions and styles of Uzbek and Tajik musical culture is one of the regions. It is worth acknowledging that the Jews of Bukhara, along with the Uzbek makoms, have made a worthy contribution to the development of Shashmakom to this day through the work of hafiz, musicians and composers, masters of their profession.

\section{THE MAIN FINDINGS AND RESULTS}

Levi Bobokhonov was the first Bukhara Jew to be invited to the palace ensembles for the first time in the second half of the XIX century during the reign of the Emir of Bukhara Muzaffarkhan. There are almost no sources about the earlier activity of the Bukhara Jews in the execution of the palace. However, it is possible to mention Levi Yahudi or Levicha, Levi Bobokhonov (1873-1926), who belonged to the Jewish nation and was one of the first to start his career as a court musician.

Levicha Hafiz's real service began in the 1890 s in the palace of the Emir of Bukhara Sayyid Alimkhan. Later, the great and great master of Shashmakom, the owner of three times the golden oriental, Levi (Levicha) Babakhani was the leader of the ensemble of musicians in the Amir's palace and personally the Amir's favorite Hafiz Qur'an, fiery singer and musician, one of the favorite performers of tambourine.

Levicha learned the art of hafiz from Borukh and Yuno Ismailov from Bukhara. Later, by order of Amir Abdullah Khan Levicha, he entrusted him to the care of the great hafiz, one of the great teachers of Shashmakom, Ota Jalal Nosirov (1945-1928), from whom he began to study the secrets of the art of makom.

Amir Alimkhan also loved Levicha's art. As a young man, Alimkhan received a special musical education and liked to play the lute and tambourine. Listening to Shashmakom in the circle of fun was one of his favorite hobbies. Hafiz Levicha was always accompanied by Amir. Alimkhan's relationship with Levicha was so close that he was allowed to cook soup, pilaf and talk with the Amir.

One of the most popular religious singing traditions among the Jews of Bukhara is called "Zamrkhaniy" and they are sung in Hebrew and Persian-Tajik languages. The Zamrs, or Zamri Dawud (Nag'mai Dawud), are the songs of David, the verses of the Book of Psalms, which have long been recited in melodies and weights within certain rules. The Jews of Bukhara and its environs performed according to melody variants [1,292].

At the beginning of the 2oth century, trade relations between Bukhara and Russia were revived. At the same time, some work is being done in the field of art. In particular, one of Riga's record companies, Pishushchiy Amur, appealed to Amir Alimkhan for permission to record Livicha Hafiz's performances on gramophone records. With the permission of Amir Alimkhan, from 1909-1911, the famous Riga gramophone firm "Pishushchiy Amur" recorded his works Talqini Sabo, Nasri Ushshak, Navruz Sabo, Ushshaki Kokand, Ufari Mogulchai Segoh and others. 
Another important aspect of Leviticus Hafiz is that when he was inspired, the beautiful peaks, the galleries, and the ecstasy of the funs left him in a state of ecstasy. Avji Turk, Zebo Pari, Muhayyari and others are singing at such a high level that fans talk about him for a long time enjoyed. Singer and musician Levicha Hafiz was awarded the title of People's Hafiz of Uzbekistan in 1934.

In the second half of the XIX century - in addition to the Jewish hafiz Levi Bobokhonov, who lived in Bukhara in the XX century, Mikhail Tolmasov, Isroil Tolmasov, Gavriil Mullakandov, Borukh Zirkiev, Moshe Bobokhonov, Neryo Aminov, Berda Dovidova, Barno Isokova and today do not live in Uzbekistan. Among the world-famous Bukhara Jewish artists Ariel Bobokhonov, Ilyos Mallaev, Muhabbat Shamaeva, Fotima Borukhova, Izro Malakov, Isak Kataev, their creative work deserves special recognition. Because they created a unique style of makom performance. It is no exaggeration to say that they also made a great contribution to the continuation and development of this classical type of music in Central Asia.

Another representative of the Jews of Bokhara, the makomdon hafiz, musician, People's Artist of Uzbekistan Mikhail Tolmasov, the most important aspects of his work and activity are, first of all, that he was a student of Levicha hafiz. In the early days of his apprenticeship, he played the frame drum and the violin next to his teacher. He then learns to memorize to the accompaniment of a tambourine. Directly under the direction of Levicha Hafiz, he thoroughly mastered the singing ways of Shashmakom.
Teacher Yunus Rajabi performed "Savti Ushshak", "Savti Navo", "Mogulchai Dugoh", "Mogulchai Segoh" (with branches) performed by Mikhail Tolmasov and quoted in Shashmaqom editions. Mikhail Tolmasov also recorded on gramophone records during his performances. As a composer, he composed musical comedies "Salvation", "Zulmi Amir".

Israil Tolmasov, a Jew from Bukhara, is his brother that he was a student and colleague of Mikhail Tolmasov. His voice was louder and thinner than his brother's, and was as close to the voice of the master hafiz Levicha in terms of beauty and sweetness. Unlike his brother, Israil Tolmasov aspired to more freedom in execution. Shashmakom tried to interpret the ways differently. He was especially skilled in the use of ghazals. Excellent examples of ghazals can be found in the audio recordings of his performances [1,314].

Gavriil Mullokandov, People's Artist of Uzbekistan, is a famous singer and musician from Bukhara, who performed Uzbek and Tajik makoms and folk songs.

From the age of twelve, Gabriel learned the frame drum from his brother Sholomo, then the flute, and then the tambourine. Gavriil first joined his brother at weddings in Sochak, Khoja Ahror, and Jamboy neighborhoods around Samarkand and sang songs such as "Rezareza," "Obi Chashm," and "Ayla-ayla" with his brother. After the death of his brother (in 1918) he continued to perform music with his younger brother Mikhail. In those years (19151920) Shashmakom's performance played an important role in the musical life of Samarkand. Later, Gavriil played the tambourine in such large forms as "Eshvoy", "Bayot", "Hayotan 
nabi" learns songs and begins to perform independently.

Gavriil Mullakandov also mastered the ways of status performed by famous hafiz, including Haji Abdulaziz's "Samarkand Ushshagi" and "Nasri Uzzol" performed by Licha hafiz. He had a unique voice, high taste and skill in memorization. His unique three-octave voice is a low octave. mi "- from" re "to the upper third octave" do "" re ". Hafiz's voice has three types of male voices - bass, baritone and tenor embodied their qualities [1,314]. Mullakandov took part in the Ten Days of Uzbek Art in Moscow in 1937 and sang "Sarakhbori Oromijon", "Kashkarchai Buzruk", "Abdurahmonbegi", "Tashkent Irogi", "Qurbon Olam" and songs such as "Tolqin", "Yor-yor". Gavriil Mullokandov will be awarded the Order of the Badge of Honor for his achievements in concerts of the decade.

Over the years, Mullokandov's songs and poems such as "Tadqini Ushshak", "Talqini Sabo", "Ufari Savti Sabo", "Kurdi Lang", "Seni" have been broadcast on the radio. In 1949, the All-Union Radio broadcast in Moscow Mullokandov's songs "Ushshaki Kokand", "Iraq Bukhara", "Talqini Uzzol", "Nasri Uzzol", "Ufari Uzzol", "Sarakhbori Oromijon", "Ufari Oromijon", "Wave", "Welcome". "," Aylanay ".

Today, the tape recordings of more than a dozen songs and poems performed by People's Artist of Uzbekistan Gavriil Mullokandov, such as "Look at the master", "Ushshaki Samarkand", "Kurbon olam", "Rezareza" are kept at the Art Research Institute.

Moshe Bobokhonov, the eldest son of Levicha Hafiz, was one of the leading figures of that time and entered the field of theatrical art. As an actor, singer and composer, he makes a worthy contribution to the formation of a new theatrical art in Bukhara. His love for the art of Shashmakom, his father's profession, was fragmentary. That is why even when he was working in the theater, he devoted his whole body to the work of Shashmakom art. Summarizing his impressions from his youth and later conversations with teachers, he summarized the results of the Bukhara Shashmakom tried to give insights into the landscapes.

Ariel Bobokhonov, the eldest son of Moshe Bobokhonov, presented the notes of Shashmaqom, written by V.Uspensky, in the hands of his father, to the scientist, professor Otanazar Matyokubov. In this collection, Moshe Bobokhonov has achieved certain results by combining the practical foundations of Shashmakom (curtain, method, form) and opinions about them, and working hard to find the theoretical basis. In particular, the pages of the collection contain comments on the composition, type, methods and structure of melodies and songs by the master musician. Apparently, Moshe Bobokhonov did a lot of creative research on Shashmakom in his time.

Today, the fund of Radio Uzbekistan has about ten parts of the Bukhara Shashmakom, recorded on magnetic tapes performed by Moshe Bobokhonov. These inscriptions serve as a reliable document on the history of Shashmakom, created by a hafiz with great potential.

Although not popular among folk artists and listeners, Borukh Zerkiev, an honored cultural worker of Uzbekistan, is one of the most influential singers from Bukhara who has made 
a worthy contribution to the development of music culture with his knowledge.

Levi Bobokhonov, a famous Bukhara hafiz who was a friend of the Zerkiev family, noticed Borukh's interest in music because of his frequent visits to his house, and advised him to take music seriously, helping to enter the Oriental Music School in Bukhara in 1921. Along with Shashmakom, Uzbek folk music was taught at the school, as well as Arabic [3,15].

Borukh Zerkiev learns Shashmakom singing from Ota Jalol Nosirov, a master artist, a wellknown representative of the professional music culture of the Uzbek and Tajik peoples. He graduated from the Oriental School of Music in 1926 and became a skilled musician and singer. Borukh Zerkiev from Shashmakom's branch plays the frame drum and sings without the tambourine. They are valuable as a document of the old style of Bukhara Shashmakom.

In 1958, when the process of recording Shashmaqom began, academician Yunus Rajabi traveled all over Uzbekistan and chose Borukh Zerkiev from Bukhara. Because Borukh Zerkiev, a native of Makodon, remembered very well the ways he learned from his teacher Ota Jalal. Yunus Rajabi records more than 82 maqom songs from Hafiz. Borukh Zerkiev knew very well the "Sarakhbor" of "Buzruk", "Rost", "Navo", "Dugoh", "Segoh", "Iraq" makoms and sang them to rhythm.

Although not known for her makom art, Fatima Borukhova is another great opera singer and classical singer of the Bukhara Jewish nation. Together with the opera, Fatima Borukhova performed classical songs and classical songs. He learned many classical music samples from his teachers and recorded them on magnetic tapes. Songs such as "Mehnat ahli" (with Halima Nosirova), "Kanalim", "Chaman ichra", "Yolgiz", "Kormadim", "Samarkand Ushshoghi", "Tashkent Iraqi", "Ey chehrasi tobonim" are among them. The services of a strong and loud voice were deservedly awarded, and in 1950 Fatima Borukhova was awarded the title of People's Artist of the Uzbek SSR.

Berda Dovidova, a People's Artist of Uzbekistan and one of the Jews of Bukhara, was born in Margilan, a beautiful city in the Fergana Valley. Unique voice owner Berda Dovidova is one of the favorite singers who has earned the respect of song lovers. he was captivated by the charming, gentle voice, his mastery of performance, especially his endless performance of makom tracks.

Berda Dovidova joined the ranks of singers of the makom ensemble, which was established at the Radio of Uzbekistan in 1960. In this ensemble, led by academician Yunus Rajabi, Berda Dovidova in a short time will master the prose of "Buzruk", "Rost", "Navo", "Dugoh", "Segoh", "Iraq". Berda Dovidova's lyrical, soft, juicy voice contributes to the performance of Shashmakom, and at the same time stands out in the ensemble as a soloist and a vocalist.

Berda Dovidova's repertoire in Shashmakom and its directions was very rich. "Bayot" I, II, V, "Nasri Bayot”, “Orazi Navo", "Talqinchai Bayot" (from "Navo" status), "Nasri Ushshak", "Ufari Ushshak", "Talqinchai Sabo" (from "Rost" status), "Munojot", "Sarabori Oromijon", "Ufari Oromijon", (from the status of "Dugoh"), "Kokand Ushshaki", "Samarkand Ushshaki", "Fergana Shahnoz" are among them. 
It has now emerged outside of Central Asia,we should also talk about the new venues of Shashmakom. This is directly related to the formation of large diasporas of Bukhara Jews in Israel and the United States. In these diasporas not only the art of makom is preserved, but also its own traditions associated with its performance are developing.

Both diasporas are home to many great musicians. Among them are generations of famous musical dynasties and makom ensembles from Uzbekistan and Tajikistan. They all continue their musical creativity. Special mention should be made of Shashmakom, who is prolonging the life of the Uzbek national maqom abroad, and Ariel Bobokhonov, llyos Mallaev, Muhabbat Shamaeva, Fotima Borukhova, Izro Malakov, Ishaq Kataev, who are promoting the art of music in the new homeland.

Another passionate follower of Bukhara Shashmaqomi is Ariel Bobokhonov, the grandson of Levicha Hafiz, the son of Moshe Bobokhonov, a musician (rubob performer) and singer. Today he is the most influential scholar, practitioner and researcher of Bukhara Shashmakomi. Ariel Bobokhonov is also a great artist and teacher of Shashmakom, who has been brought up in all respects and has perfectly developed his abilities.

Ariel Bobokhonov captured the Bukhara ancestral art "Shashmaqom" preserved in the chest of his grandfather Levicha Hafiz, and restored the original version of some forgotten makom performances by Ariel Bobokhonov. In this regard, the President of Uzbekistan sent a letter to Ariel Bobokhonov and awarded him the Commonwealth Order [4. , 8).
Ilyas Mallaev, a Bukhara artist, an honored artist of Uzbekistan, has left a bright mark on the history of Shashmakom.

But although his creative activity was related to music, his original dream, his imagination, was focused on traditional classical music, especially the field of Shashmakom. Tashkent, Samarkand, Bukhara,

There will be many conversations with senior status teachers living in Dushanbe and elsewhere. He will be able to find unique sound recordings in the archives of Moscow and St. Petersburg without melting. In particular, in 1909, Levicha rediscovered Hafiz's performances by Riga's Pishushchiy Amur, and in 1984, on the occasion of the 110th anniversary of Hafiz's birth, he republished a short version of these recordings.

In 1992, llyas Mallaev retired and began living in the United States with his family. Ilyas Mallaev attributes this to the negative political attitude toward Jews in the 1980s, during the Soviet era, and the fact that the United States opened its doors to the Jews, including the Jews of Bukhara. As soon as he arrived in New York, he united the musicians and singers here and began to promote the musical traditions he had mastered in Uzbekistan and Tajikistan.

Ilyas Mallaev, who formed the Makom ensemble of 30 musicians and hafiz in early 1993, introduced Navo's makom songs (from Sarabor to Ufari Bayot, excluding Savti and Mughals) that same year.

Ilyas Mallaev's wife, People's Artist of Uzbekistan Muhabbat Shamaeva, as mentioned above, did not abandon her work like many Bukhara Jews. His wife is an active member of the Makom ensemble, founded by 
the late Honored Artist of Uzbekistan Ilyas Mallaev.

The legendary singer of the song "Kurban Olam" Izro Malakov is a native of Bukhara. His ancestors came to Bukhara thousands of years ago. Since he was interested in makom from a young age, he learned a lesson in the direction of Shashmakom from his great teachers before him takes, he has lived in America since 1992. Today, Izro Malakov shares his knowledge with young people at a special academy he founded.

Izro Malakov is now eighty years old. He devoted his entire life to the great work of art of the Uzbek and Tajik peoples "Makom". No moment of his life can be imagined without "Shoshmakom".

Izro Malakov was awarded the honorary title of "People's Artist of the Republic of Uzbekistan" for many years of fruitful work, the development of Uzbek makom art, his contribution to the promotion of the rich cultural heritage of our people in the world.

\section{CONCLUSION}

People's Artist of Uzbekistan Izro Malakov has more than 120 students in different parts of the United States singing "Shoshmakom". These are 120 young American girls, of all nationalities and ethnicities, who do not know the Uzbek language at all, American singers are singing in Uzbek, the great cultural heritage of the Uzbeks, "Shoshmakom".

People's Artist of Uzbekistan Muhabbat Shamaeva, Honored Artist of Uzbekistan Ishak Kataev, People's Artist of Uzbekistan Izro Malakov, strong voices Abuhay Aminov and Achil Ibragimov, Avrom and Shumiel Tolmasov, Roshel Rubinov, Iosif Abramov and Osher
Baraev, living in the United States today. They are teaching young people their ways.

\section{REFERENCES}

1. Matyoqubov O. Authority. -T .: Music Publishing House. 2004. B.292,

2. Moshe Boboxonov about Taken from Matyokubov's book Maqomat.

3. Sources Otanazar

4. Olimboeva K., Yuldoshboeva T., Ahmedov M., Mirzaev T. Folk musicians of Uzbekistan. -T: Literature named after Ghafur Ghulam and art publishing. 1974. B. 15

5. Contemporary magazine. № 3 /l Toshkent. 2005. P. 8 